\title{
Global Model of Information Publishing Administration by Municipality in The Area of Property and Economic Performance in The Slovak Republic
}

\author{
Eva MIHALIKOVÁ ${ }^{\star *}$, Darina KOREŇOVÁ² \\ 1, 2 Pavol Jozef Šafarik University in Košice, Faculty of Public Administration, Department of Economics and Management \\ of Public Administration, Popradská 66, 04011 Košice, Slovak republic, \\ E-mail: eva.mihalikova1@upjs.sk¹, darina.korenova@upjs.sk² \\ * Corresponding Author
}

Received: 05.07.2021
Accepted: 23.08.2021
Published: 23.10.2021 DOI: $\underline{\text { 10.47750/QAS/22.184.19 }}$

\begin{abstract}
Publishing information becomes more important because it increases the clarity and transparency of public administration and helps to measure, monitor and manage countries. An important starting point is to set minimum legal requirements (the range of information that should be published and made available to the public across the $E U)$. This requires the creation of new or updated standards and guidelines that would bring more transparent, understandable and comparable EU-wide information. The EU also creates various databases, which are an important official information resource. The aim of countries is to provide a comprehensive set of information at a global level and to improve the relevance, consistency and comparability of published information. Each member states of the European Union (including Slovakia) are responding to the increased need for information. The aim of the article is to point to obligatory published information of the local self-government in the Slovak Republic. Process modeling has been chosen as a central method in this article. The intention of this paper is to raise public awareness in order to build a modern public administration.
\end{abstract}

Keywords: municipality, economic information, publishing, model, economic performance, municipality property.

\section{Introduction}

The basis for good governance in public administration is to improve the availability and quality of information to the public. The high quality of information produced can become a competitive advantage for the organization (Azemi et. al, 2017). Publishing the information shall contribute to better information provision to the citizens on planned and implemented activities of particular public administration bodies and on administrative procedures of carrying out citizens' requests on one hand, and mobilize the citizens to increased interest in solving their issues in a more effective and faster way, i.e. via e-mails, and in public matters on the other hand. Local self-government is closest to citizens. Municipality is an obliged subject with legal duty to publish a lot of information (based on the Act of Free Information Access).

The aim of the article is to point to obligatory published information of the local self-government in the Slovak Republic. The paper is furthermore focused on selected area of information related to municipal property and economic performance.

Process modeling has been chosen as a central method in this article. A global model was used to identify the process systems and the relation between them. The model is thus valuable exactly as a decision-making support tool for public administration (de Lancer Julnes, 2000).

\section{Subject matter formulation}

Based on the Act of Free Information Access, municipality represents an obliged subject with legal duty to publish certain information. This duty was imposed on the municipalities by further regulations, namely the Municipal Establishment Act, Administration Order and a few other Acts. Requirements of these acts were reflected in the rules determining the following information subject to obligatory publishing by the municipalities (Rules of publishing information through the Internet website of municipality, 2013):

Information on municipal self government;

- Information on municipality economic performance and property;

- Information published and made available pursuant to special regulations;

- Information on legal entities founded and established by the municipality, and on companies with business interest of the municipality.

However, the rules indicate much higher extent of published information in sake of ensuring the highest transparency and as many as possible citizens informed, since they are the main source of municipality tax income and have right to control its activity and economic performance.

In the presented article, we drawn the attention to information on the municipality property and economic performance.

Along with identification of mandatorily published information, the above stated acts stipulate various forms of 
publishing. Active approach of the municipality to information publishing via Internet represents the best conditions for information provision to the public and to public control. The potential contribution of the internet is to enhancing the interactivity, transparency and openness of public sector entities (Špaček, 2018).

Such method of information presentation is supported also by the mentioned rules stipulating that information that should be obligatorily published by the municipality also in other manner, shall be published also on the municipality website operated by them, taking care to ensure up to date, complete and properly structured information presented (Rules of publishing information through the Internet website of municipality, 2013). It is mainly information that helps a citizen to orientate himself in obtaining information on the local selfgovernment activities and eventual communication with it. Thus, information should be actively published by the municipality (Mihaliková, Koreňová, 2018).

If the municipality doesn't operate a website or doesn't publish information there on that should be published, citizens are entitled to such information and can require it from the municipality pursuant to the Act of Free Information Access.

\section{Methodology}

Modelling of the business system was the common too exploited in the private sector, however has found its stabile position under the conditions of the self-government of the Slovak Republic. It affords the significant knowledge on the self-government processes and leads to their upgrading, either in the form of the inevitable modification of the effective legislation or without the need to execute such modifications (Fričová, Čepelová, 2014).

The article is aimed at creating a global model of information publishing control in the Slovak Republic conditions, focusing on area of information related to municipal property and economic performance. The model is valuable exactly as a decision-making support tool for public administration (Šanda, Křupka, 2018).

Models (be it global or detail) represent a key tool for solution of a real object complicated nature. They are used for application of effective management in both private and public sector, for implementation of new SW solutions, optimizing of organizational processes, etc. Territorial self-government in
Slovakia, represented by its fundamental unit - municipality often struggle many competences assigned. Modeling of its original or transferred competences (rights and obligations) allows making transparent the extent of assigned, required or desirable by the municipality activities.

Process modeling has been chosen as a central method in this article. Abstraction represents the main modeling denominator. Process model is aimed at distinguishing major process elements from those trivial.

In particular, global process model purposely monitors the system complexity but not in the form of details. Considering the time, global model is perceived as timely universal, statically focused on the existence of elements and their interactions (offering view son processes as on objects, system of processes and their mutual relations) (Řepa, 2012).

The Eriksson - Penker notation has been used to create a process system global model, developed as a specialization of class diagram from UML language. $\mathrm{H}$. E. Eriksson and $\mathrm{M}$. Penker (2000) are the notation authors. Accordingly, we determine four basic elements of the global model: processes, goals, sources, and rules.

Since every process is primarily focused on a customer, the following customers can be identified within the created global model:

- Internal customers - employees of municipal office, municipal bodies,

-External customers - citizens, state administration and selfgovernment, organizations and public administration institutions, and private sector subjects.

\section{Problem analysis}

At first, we shall focus on the information obligatorily published on the municipality website by municipalities through created Global Model of Information Publishing Report by Municipalities in the Slovak Conditions, as illustrated in Figure 1. This model precedes the targeted model as for contents. It illustrates the areas of mandatory information publishing by municipality, namely information on municipal self-government, municipal economic performance and property, legal entities founded and established by the municipality, companies with business interest of the municipality, and information published and made accessible pursuant to special regulations.

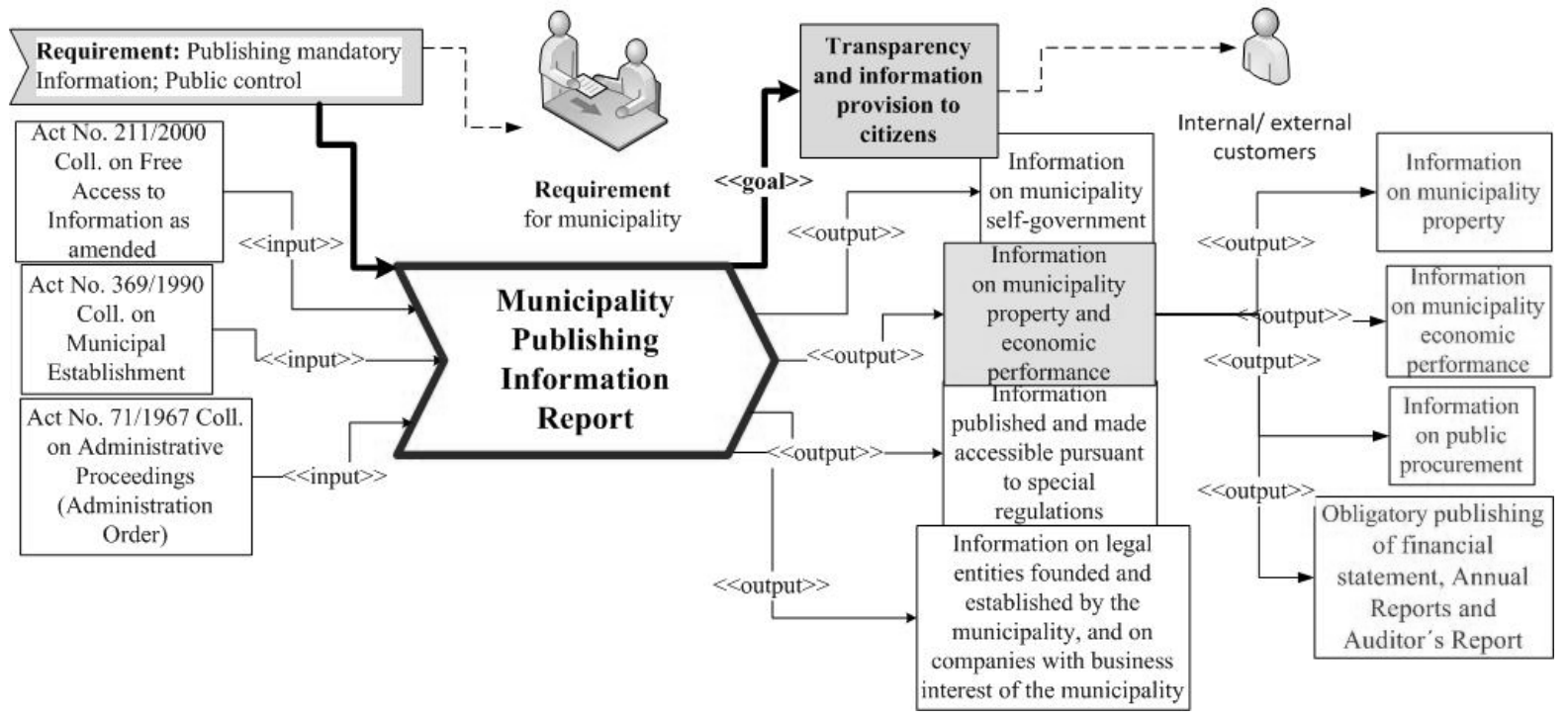

Figure 1. Global model of Information Publishing Report by Municipalities in the Slovak Conditions 


\subsection{Publishing information on municipality economic performance}

The article is furthermore focused on one of the areas illustrated on Picture 1 - Information on municipality economic performance. This area is regulated by many laws. It is divided into 3 sub-processes.

\section{Information about subsidies}

The obligatory published information of the local selfgovernment are information on: the subsidies, the grants received by the municipality, as well as the subsidies provided by the municipality.

Subsidies and grants are part of transfers in the public administration. The municipality publishes where transfers were obtained (they are from the European Union, the state budget or other sources), the amount of transfer, the amount of the coparticipation of the municipality, the purpose of transfer and also a report and the financial statement.

Based on the Act No. 583/2004 Coll. on Territorial SelfGovernment Budgetary Rules as amended, municipalities may also be providers of subsidies. The municipal council decides about subsidies from the municipality budget using the generally mandatory regulations, which the municipality publishes on its website with the following documents:

List of grant applicants: Applicant eligibility, estimated budget and level of Co- financing, the purpose of the subsidy, the results of the evaluation of the proposals (the reason for acceptance or nonacceptance)

List of subsidies granted: information on the recipient of the subsidy, the purpose of the subsidy, an amount of money given to applicant by the local self-government;

Memorandum of the meeting of the commission, which assesses applications for subsidy;

The subsidy reports, the financial statements of subsidies.

\section{Publishing of budgets and final accounts}

Act No. 583/2004 Coll. on Territorial Self-Government Budgetary Rules as amended states that the municipality budget is a fundamental tool of financial performance in respective fiscal year that funding of municipality tasks and functions depends on. Draft budget is subject to approval by the municipal representatives and before it shall be published for at least 15 days in the manner usual at particular municipality (§ 9 clause 2 Act No. 369/1990 Coll. on Municipal Establishment). Preparing the municipality budget, the Act of Municipal Establishment doesn't stipulate the budget publishing on the municipality website but only doing it in the manner usual at particular municipality. Since towns and cities are obliged to develop their websites ( $\$ 6$ clause 1 Act No. $211 / 2000$ Coll.), published information on website is also considered publishing in the manner usual at particular municipality.

Similar principles to those applicable to budgets apply also to the municipality final accounts publishing. Draft final account of municipality shall be approved by municipal representatives; the draft is submitted for discussion at the Municipal Office by the Mayor. Final accounts of the municipality shall be prepared according to the statement of finances. Based on the Act of Territorial Self-Government Budgetary Rules, Final Accounts shall contain seven basic sections along with introduction and enclosures, namely: information on fulfillment of cost and revenues, assets and liabilities, overview of debt status and prognosis, overview of provided guarantees, fulfillment of budget, economic performance of contributory organizations and information of cost and revenues related to business activities. Before the approval of the draft municipality Fina Accounts at the Municipal Office, the municipality comptroller must prepare the expert standpoint thereto ( $\S 18 \mathrm{f}$ clause 1 item c) Act No. 369/1990 Coll.). Draft budget is subject to approval by the municipal representatives and before it shall be published for at least 15 days in the manner usual at particular municipality ( $\$ 9$ clause 2 Act No. 369/1990 Coll.) so as the citizens can make comments thereto (How should local selfgovernment publish information).

\section{Publishing of financial statement, Annual Reports and Auditor's Report}

Based on the Act No. 431/2002 Coll. on Bookkeeping as amended, the financial statements present the facts that are the subject of accounting. Financial statements are provided to persons using the financial information (the users of accounting information).

Financial statement represents an accounting record where assets, liabilities, equity, cost, revenues, resulting profit/ loss and other assets and liabilities are documented in the form of records whose form and contents are determined by the Slovak Ministry of Treasury. Financial statement is considered as prepared after attaching signatures to the general requirements of the financial statement and its particular enclosures.

Every financial statement shall be entered in the Register of Financial Statements, being an IS of public administration (Register of Financial Statements). Register administrator shal enter, publish and make available every delivered document as stored by the accounting unit, at the latest within 5 business days from the date of delivery to the Register in its public or non-public section.

Municipalities shall have their financial statements audited by auditor. If the financial statement becomes subject to audit, the auditor shall examine the accounting unit in order to express their opinion on the financial statement and financial standing of the accounting unit in the Auditor's Report.

Accounting units that are obliged to have their financial statement examined and verified by auditor shall prepare also the Annual Report (Šlosárová et al., 2006). Annual Report shall contain financial statement for respective fiscal period and Auditor's Report on the financial statement, except otherwise stipulated in special regulation, and further information (e.g. development of the accounting unit, research and development cost, proposed distribution of profit or coverage of loss, etc.). Similar to the financial statement, the Auditor's Report and Annual Report shall be stored in the Register of Financial Statements. Financial and accounting information about public entities is a rich source of information about their activity (Sedmihradská, 2018).

\subsection{Publishing information on municipality property}

Property is an important economic tool for the community. Municipality property can influence the municipality's socioeconomic development, community life and business activities (Matoušková et al., 2000). Based on the Act of Municipal Establishment, municipality property can by used to:

Public purposes - his property provides public benefit services and creates conditions for the quality of life of the population

Self-governing purposes - this property ensures the performance of original and transferred 
competencies of local self-government, activity of the Municipal Office,

Entrepreneurial activity - and business, the main objective of this property is to bring additional revenue to the budget.

Based on the Act No. 138/1991 Coll. on property of municipalities as amended, the municipality manages its property independently or through the property manager of the municipality. The municipality manages its property in order to develop the community and citizens and to protect and create the environment. The municipality is obliged to increase, protect and valorize the property. The municipal council approves the principles of property management that must be published by municipality. The municipality is obliged to publish a statement of the intention to sell their property and the way with the conditions of the tender or auction for at least 15 days. The property may be sold directly at least for the price in the amount of the general value of the property determined according to special regulations. At the same time, it also publishes a deadline for the delivery of price offers on the official notice board, website and regional press. The municipality publishes the information about the sold property, the transfer of ownership of the property of the municipality and all reports and information concerning the property of the municipality, which were discussed by the municipal council.

\subsection{Publishing information on public procurements}

Public procurement lays down rules and procedures for awarding contracts, concessions and design contests. (It is regulated by Act No. 343/2015 Coll. on Public Procurement as amended). Public procurement means purchasing supplies, contracting for services, organizing design contests, contracting for public works, awarding public works concessions and service concessions by contracting authorities, and contracting for public works by concessionaires of public works concessions. The municipality is considered to be a contracting authority and draws up a public procurement plan. The municipal council approves generally mandatory regulations on public procurement procedures in the municipality, which must be published on the municipality's website. The contracting authority is required to organize a procurement procedure as an open procedure or a restricted procedure. An invitation to tender must be published on the website of the municipality. These documents are sent for publication to:

The Publications Office of the European Union, which will publish them in the Official Journal of the European Union (in the case of public procurement above EU thresholds),

The Public Procurement Office, which publishes them in electronic form in the national Journal of Public Procurement (public procurement below EU thresholds).

Public procurement data and the necessary documents are published in the Central Register of Contracts, which includes the date of publication, the contracting authority and the contract. Each contract contains the identification data of the contracting authority, the type of procurement, the notification number from the e-Journal and other necessary documents (Evaluation of tenders and declaration of tender successful). At the same time, the municipality prepares and publishes a final public procurement report where the municipality publish information on the value of the contract, the subject of the contract, etc.

\subsection{Publishing of contracts, orders and invoices}

Pursuant to Act No. 40/1964 Coll. (Civil Code) as amended, and Act No. 211/ 2000 Coll. on Free Access to Information as amended, all municipalities, towns, and self-governing regions and organizations founded by them are obliged to publish contracts, invoices and orders on their websites, provided that such contracts, invoices and orders is obligatory that are associated with public funds, property owned by the state, municipality, higher territorial whole or legal entities founded upon law. If they don't operate their own website, their contracts can be published for free in the Commercial Journal or on portals intended for this purpose (Contracts are usually published in the Central Register of Contracts (CRS)).

Obligation to publish contracts related to public funds became effective on January 01, 2011. We should state that contracts of work or service contracts must be concluded in compliance with Act No. 343/2015 Coll. on Public Procurement as amended, and recorded in the Register of Contracts in Effect.

Municipality as a subject obliged shall publish orders of the goods and services on its website within 10 days from the ordering date. This shall not apply to orders related to already published contract. Invoices shall be published on the obliged subject's website within 10 days from delivery to the subject obliged but at the latest within 30 days from invoice settlement. Publishing of invoices and orders apply only to subjects obliged with own Internet website (Publishing of contracts - information for municipalities).

\section{The results and discussion}

In the following section, publishing of the above stated documents is expressed through a global model. The global model of information publishing by municipality in conditions of the Slovak Republic, focused on the area of information on the municipality economic performance and property, is illustrated in Figure 2 and Figure 3. It consists of four basic processes:

INF_1 Contracts, Orders and Invoices Publishing Management;

INF_2 Information on Municipality Property Publishing Management;

INF 3 Information on Municipality Economic performance Publishing Management;

INF 4 Information on Public Procurement Publishing Management.

Each of these processes has inputs and outputs allocated. Valid legal regulation applicable to particular area represents the most frequent process support. Output refers to acceptable form of information publishing (e.g. official billboard, Internet website, and respective registers). Requirement of due information publishing and subsequent public control represents a summary requirement applicable to all processes. This model is aimed at ensuring transparency and information awareness by the citizens as a key intention of public administration approximation to the citizens (as a public power source). A citizen is concurrently the main process customer within municipality. The stated requirement and goal are identical to both presented models. 


\section{GENERAL MANAGEMENT}

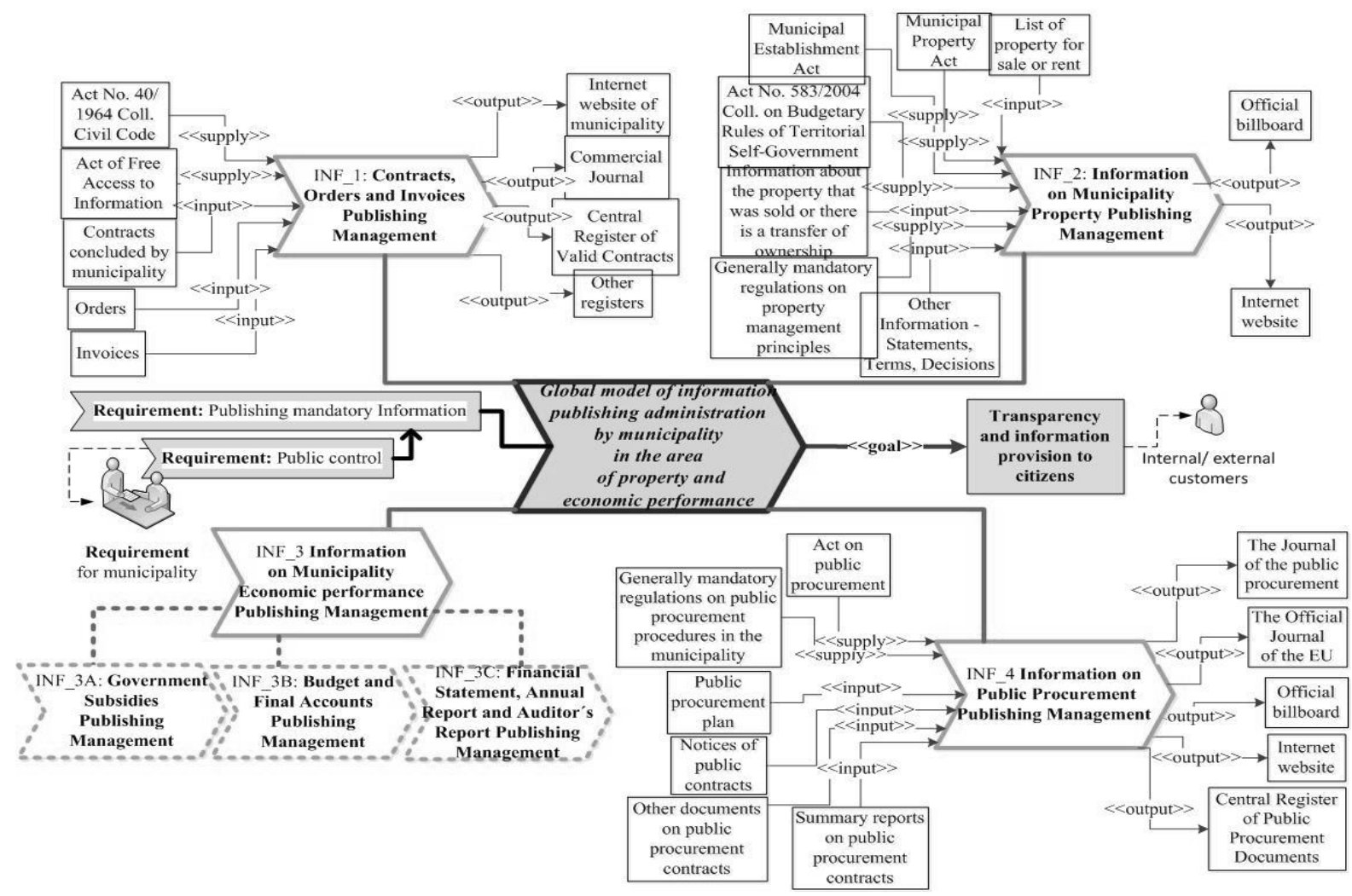

Figure 2: Global model of information publishing administration by municipality in the area of property and economic performance

\section{Source: Self-elaboration}

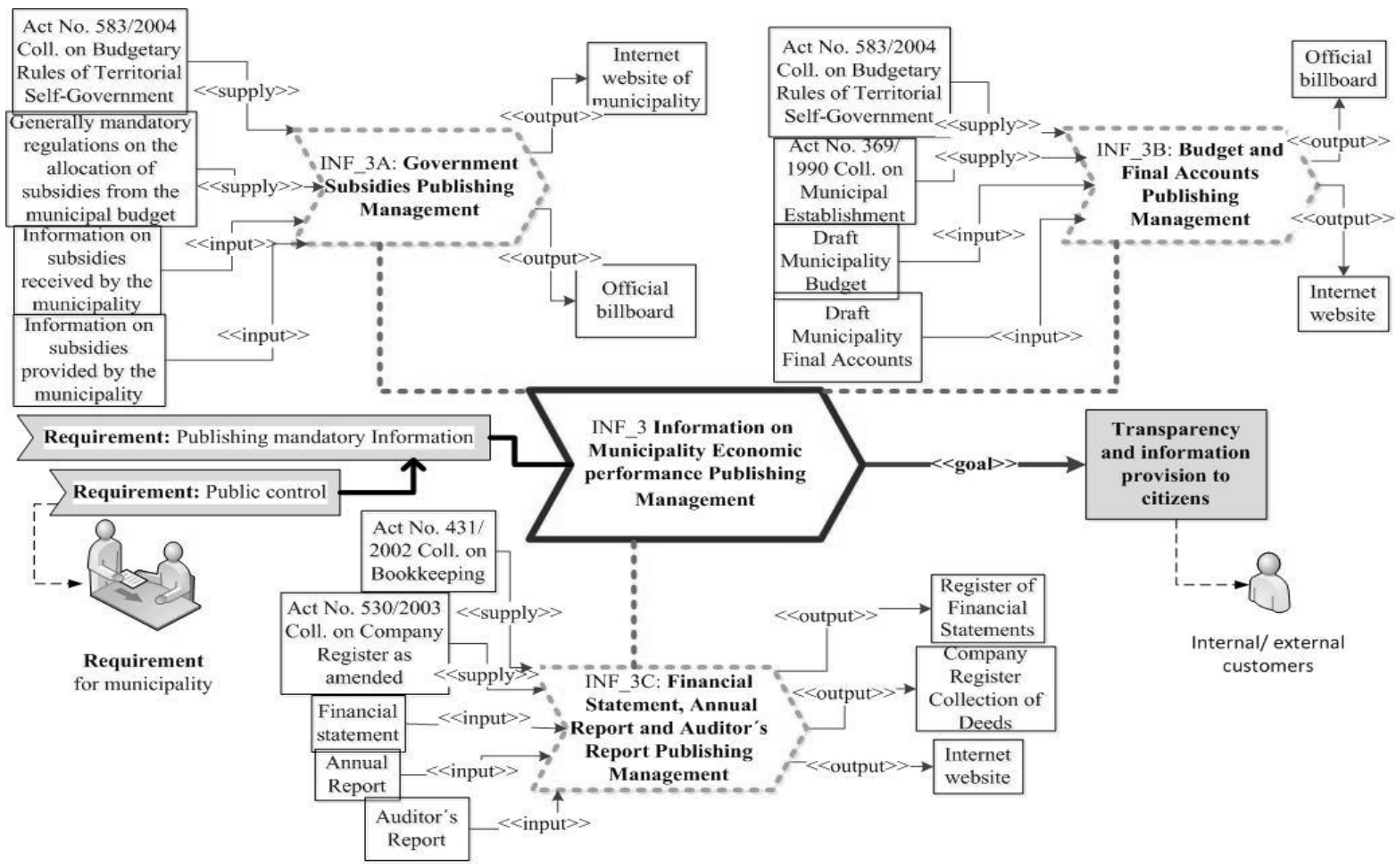

Figure 3: Global model of information publishing administration by municipality in the area of economic performance Source: Self-elaboration

Value of information has been currently continuously increasing with electronic acquisition of information becoming ever more important. Public administration, including municipalities, considers the information one of the most 
significant tools, the basis of correct decisions, better performance and satisfaction of the public. Public administration sector is obliged to publish selected information pursuant to Act No. 211/2000 Coll. on Free Access to Information, the Slovak Constitution and other legal regulations.

The aim of the model was to support the basic goal of open public administration. The model will increase municipal transparency and public awareness. The available and quality information and services are the basic criteria for evaluating municipalities. The model identifies inputs (presented by laws and documents that need to be published) and outputs of the process (pointing to ways of publishing information). Graphical visualization of the information publishing process can be helpful to municipalities and the public for better orientation in the economic information. It is also a good idea to divide the information about the municipality economic performance and property into four areas when they are published on the websites of municipalities. Unity in presenting information on the internet (on the website of the municipality) helps citizens understand: Where information can be found and what is the content of the information. Citizens can evaluate the activity of the municipalities, ineffective handling of public funds or missing mandatory information.

\section{Conclusion}

In the world of digital technologies, Internet has been considered the most effective mean of information provision. Information spread much faster in the Internet environment, it is accessible at any time from any place; thus this method has become the basis for provision of all information that subjects obliged are to publish pursuant to the Act on Free Information Access.

Municipality (as a subject obliged) is obliged to publish selected information. The Information Disclosure System is based on the ability to search and retrieve the published information. Our article reviewed and determined obligatorily published information on property and financial performance by municipalities through a model illustration. The analysis indicates the legal duty to publish municipal documents on their websites, or in respective electronic registers. Such information is of primary importance in the terms of fundamental economic information intended for the publishing. Published economic information increases the degree of citizens' knowledge about economic aspects of self-government.

Finally, we can state that implementation of information communication technology in all public administration processes significantly contributes to increased information awareness of the citizens. This shall ensure higher transparency and more effective public administration performance control through engagement of the citizens in the res public control. According to Nemec (2108) the transparency and accountability case documents that transparency does hot automatically deliver accountability and better performance.

\section{References}

[1] Azemi, N. A., Zaidi, H., \& Hussin, N. (2018). Information Quality in Organization for Better Decision-Making. International Journal of Academic Research in Business and Social Sciences, 7(12), 429-439. doi:10.6007/ijarbss/v7-i12/3624

[2] De Lancer Julnes, P. (2000). Decision-making tools for public productivity improvement: a comparison of DEA to cost-benefit and regression analyses(1). Journal of Public Budgeting, Accounting \& Financial Management, 12(4), 625-648. doi:10.1108/jpbafm-12-04-2000-b006
[3] Fričová, D. and Čepelová, A. (2014). Process management and process modelling in territorial self-government of Slovakia. Political Sciences, Law, Finance, Economics and Tourism: international multidisciplinary scientific conferences on social sciences and arts. Sofia: STEF92 Technology, pp. 311-318.

[4] Eriksson, H. E. and Penker, M. (2000). Business Modeling with UML: Business Patterns at Work. John Wiley \& Sons.

[5] How should local self-government publish information. At $<$ http://samosprava.institute.sk/ako-ma-samosprava-zverejnovatinformacie-o-svojej-cinnosti-na-webstranke-a-uradnejtabuli\#.YOBR9-gzaM8>, accessed 7 April 2021.

[6] Matoušková, Z., Macháček J., Postránecký, J. and Tóth, P. (2000). Regional and municipal economics. Praha: VŠE.

[7] Mihaliková, E. and Koreňová, D. (2018). Model of economic information publishing process in conditions of municipalities in the Slovak Republic. Public Administration 2018. Proceedings of the 12th International Scientific Conference. Pardubice: University of Pardubice, pp. 145-153.

[8] Nemec, J. (2018). Public Administration Reforms in Slovakia: Limited Outcomes (Why?). NISPAcee Journal of Public Administration and Policy, 11(1), 115-134. doi:10.2478/nispa2018-0005

[9] Publishing of contracts - information for municipalities. At $<$ https://www.minv.sk/?postup-samosprav-pri-povinnomzverejnovani-zmluv-faktur-a-objednavok-podla-zakona-c-5462010-z-z-3>, accessed 13 April 2021

[10] Register of Financial Statements. At $<$ http://www.registeruz.sk/cruz-public/home/faq>, accessed 15 April 2021.

[11] Řepa, V. (2012). Procesně řízená organizace. Praha: Grada Publishing.

[12] Rules of publishing information through the Internet website of municipality. 2013. $<$ https://www.slideshare.net/INSTITUTEsk/pravidl-zverejovaniainformci-prostrednctvom-internetovej-strnky-obce>, accessed 22 April 2021.

[13] Sedmihradská, L. (2018). Inter-Municipal Cooperation in the Czech Republic: A Public Finance Perspective. NISPAcee Journal of Public Administration and Policy, 11(2), 153-170. doi:10.2478/nispa-2018-0017

[14] ŠANDA, M., \& KŘUPKA, J. (2018). Quality of life evaluation as decision support in public administration for innovation and regions development. ADMINISTRATIE SI MANAGEMENT PUBLIC, (30), 51-66. doi:10.24818/amp/2018.30-04

[15] Šlosarová, A. et al. (2006). Financial Statement Analysis. Bratislava: Ekonómia.

[16] Špaček, D. (2018). Social Media Use in Public Administration: The Case of Facebook Use by Czech Regions. NISPAcee Journal of Public Administration and Policy, 11(2), 199-218. doi:10.2478/nispa-2018-0019.

[17] Act No. 369/1990 Coll. on Municipal Establishment as amended

[18] Act No. 211/2000 Coll. on Free Access to Information as amended

[19] Act No. 431/2002 Coll. on Bookkeeping as amended

[20] Act No. 583/2004 Coll. on Budgetary Rules of Territorial SelfGovernment as amended

[21] Act No. 40/1964 Coll. Civil Code as amended

[22] Act No. 343/2015 Coll. on Public Procurement as amended

[23] Act No. 138/1991 Coll. on Municipal Property 